
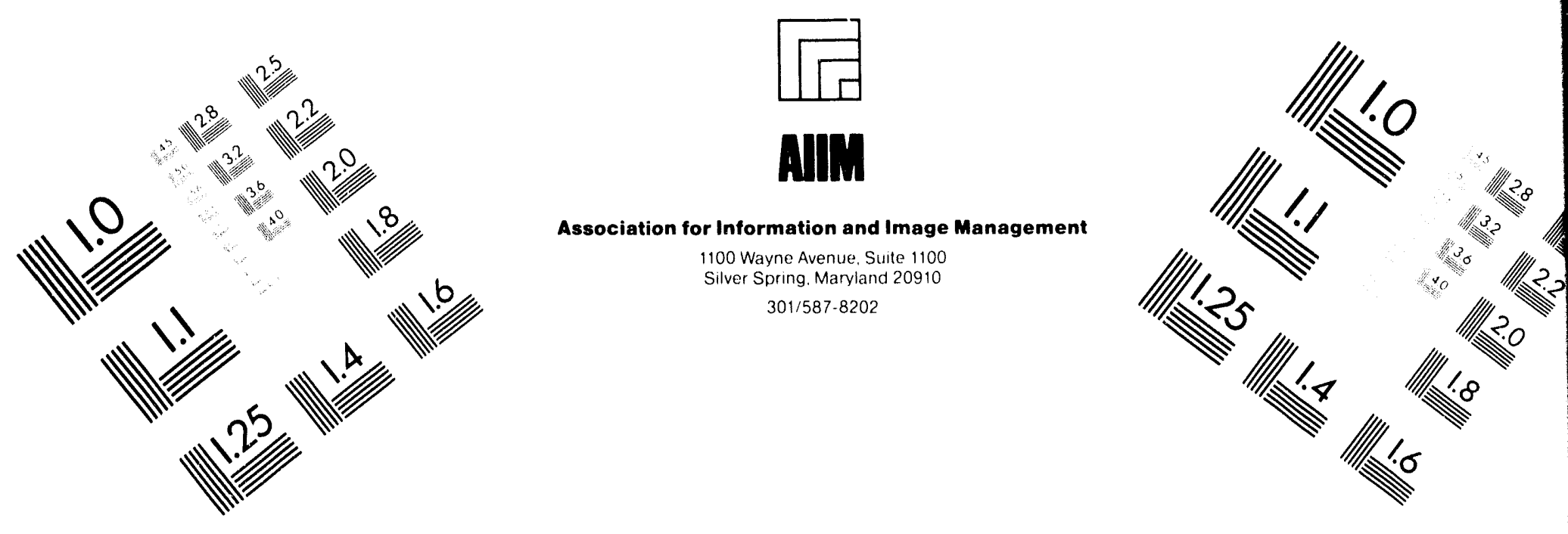

\title{
Centimeter
}

1
$\mid$

Inches
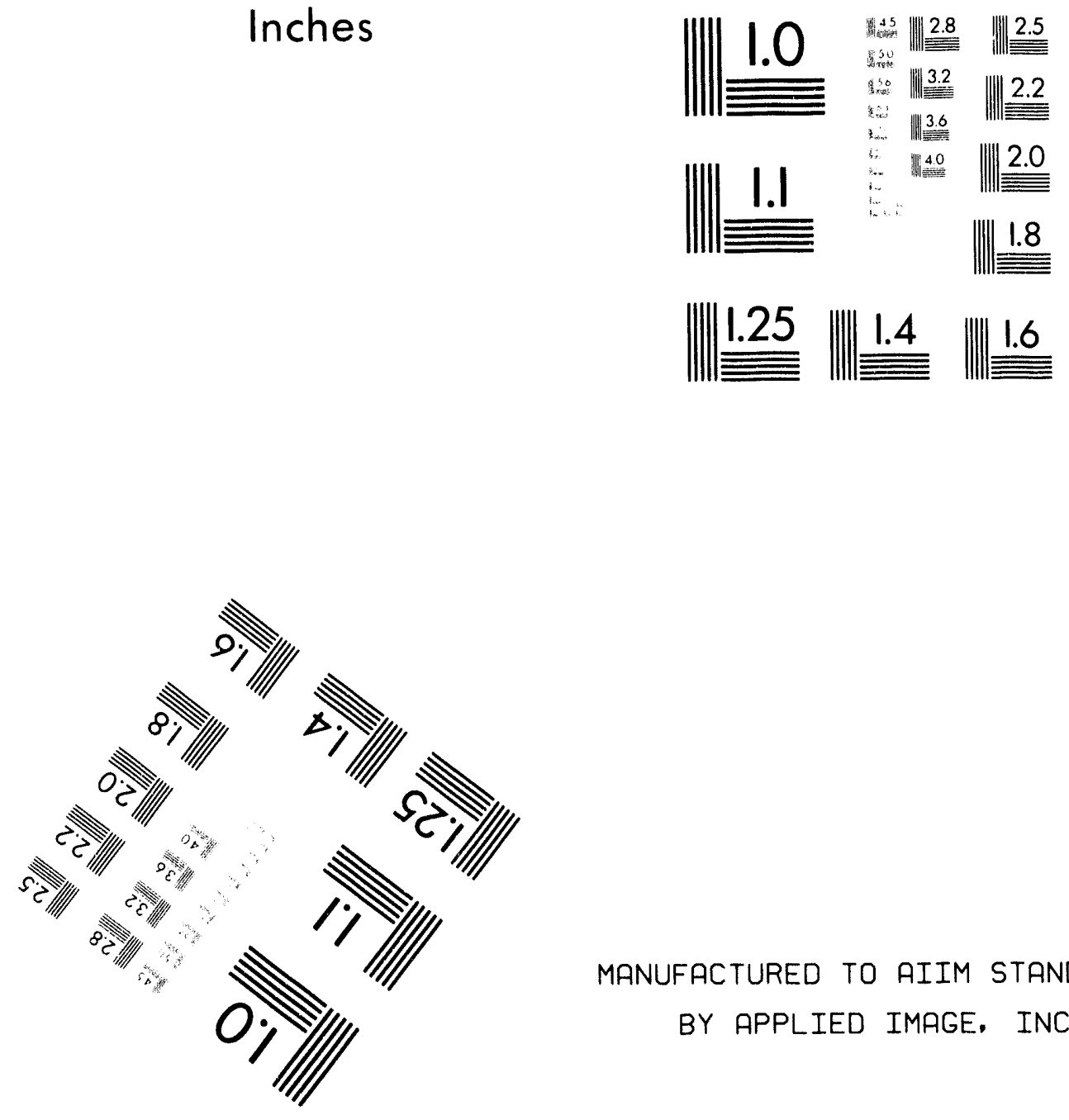

MANUFACTURED TO AIIM STANDARDS

BY APPLIED IMAGE. INC.

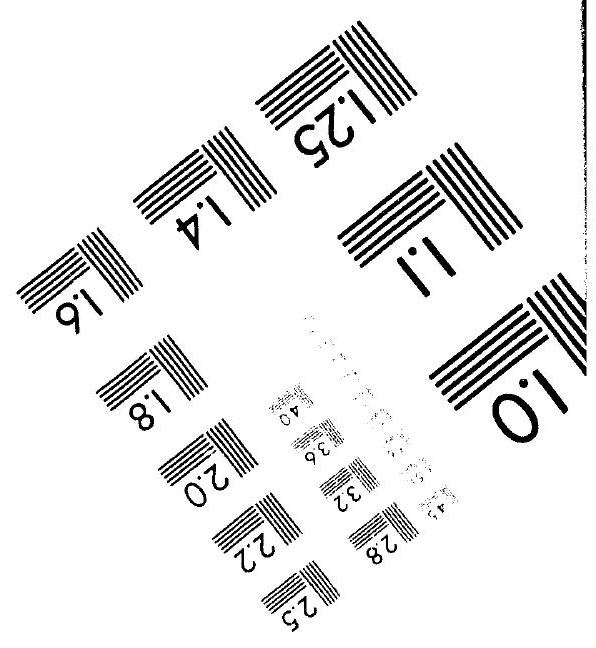



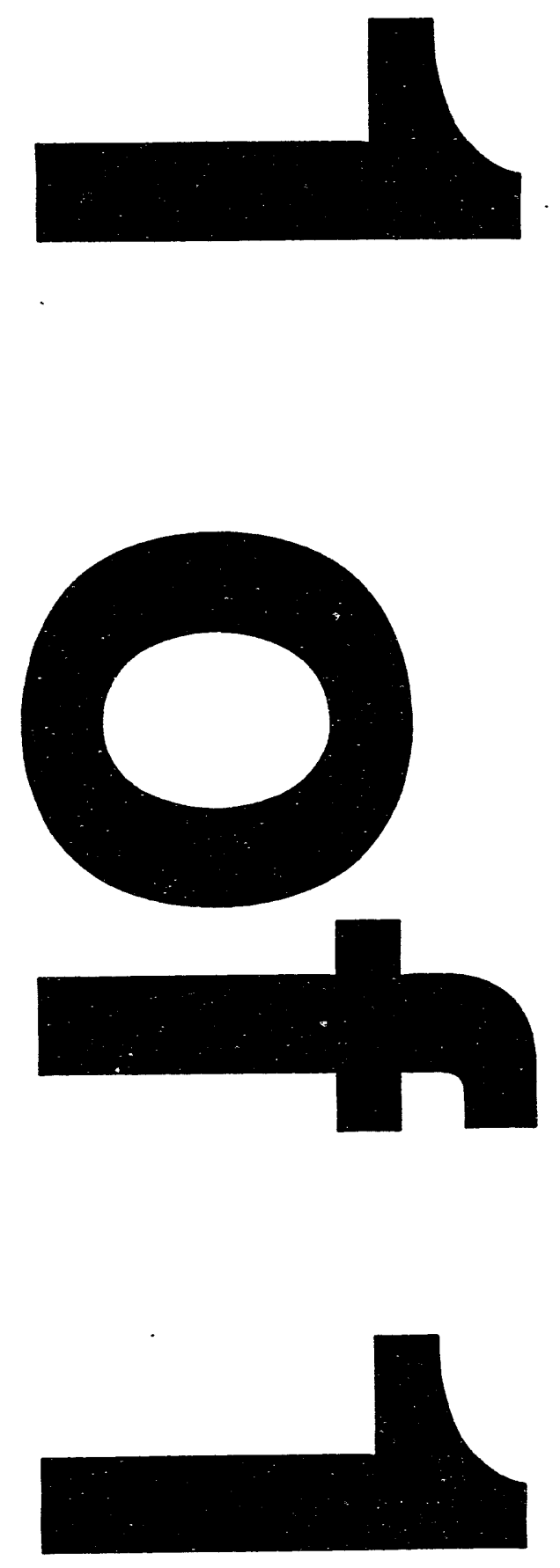
WSRC-TR-94-0194

GUIDELINES FOR ACCEPTABLE SOIL CONCENTRATIONS IN THE. OLD F- AND H-AREA RETENTION BASINS

D.M. Hamby

Westinghouse Savannah River Company

Savannah River Site

Aiken, SC 29808 


\section{GUIDELINES FOR ACCEPTABLE SOIL CONCENTRATIONS IN THE OLD F- AND H-AREA RETENTION BASINS}

by

Hamby, D. M.

Westinghouse Savannah River Company

Savannah River Site

Aiken, South Carolina 29808

This paper was prepared in connection with work done under the above contract number with the U.S.

Department of Energy. By acceptance of this paper, the publisher and/or recipient acknowledges the U.S.

Government's right to retain a nonexclusive, royalty-free license in and to any copyright covering this paper, along with the right to reproduce and to authorize others to reproduce all or part of the copyrighted paper. 


\section{DISCLAIMER}

This report was prepared as an account of work sponsored by an agency of the United States Government. Neither the United States Government nor any agency thereof, nor any of their employees, makes any warranty, express or implied, or assumes any legal liability or responsibility for the accuracy, completeness, or usefulness of any information, apparatus, product, or process disclosed, or represents that its use would not infringe privately owned rights. Reference herein to any specific commercial product, process, or service by trade name, trademark, manufacturer, or otherwise does not necessarily constitute or imply its endorsement, recommendation, or favoring by the United States Government or any agency thereof. The views and opinions of authors expressed herein do not necessarily state or reflect those of the United. States Government or any agency thereof.

This report has been reproduced directly from the best available copy.

Available to DOE and DOE contractors from the Office of Scientific and Technical Information, P. O. Box 62, Oak Ridge, TN 37831; prices available from (615) $576-8401$.

Available to the public from the National Technical Information Service, U. S. Department of Commerce, 5285 Port Royal Rd., Springfield, VA 22161 
WSRC-TR-94-0194

GUIDELINES FOR ACCEPTABLE SOIL CONCENTRATIONS IN THE OLD F- AND H-AREA RETENTION BASINS

D.M. Hamby

April 18, 1994

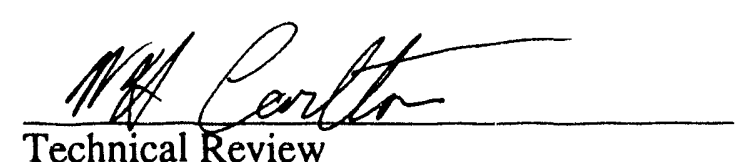

Westinghouse Savannah River Company Savannah River Site Aiken, SC 29808 


\title{
GUIDELINES FOR ACCEPTABLE SOIL CONCENTRATIONS IN THE OLD F- AND H-AREA RETENTION BASINS
}

\author{
D.M. Hamby
}

\section{SUMMARY}

Concentration guidelines for residual radionuclides in soil at the sites of the Old F- and H-Area Retention Basins (281-3F, 281-3H) have been calculated using a dose-based approach. The guidelines also are being applied to areas around the F-Basin's Process Line. Estimation of these soil guidelines was completed using RESRAD 5.0 in accordance with the DOE RESRAD methodology specified in DOE/CH/8901 (Gi89). Guidelines are provided for the nuclides known to be present in the soils at each basin (Sc87). Soil and hydrologic characteristics specific to each basin are defined for the areas above, within, and beneath the contaminated zones.

\section{INTRODUCTION}

A soil concentration guideline is defined as a radionuclide concentration in soil that is acceptable, i.e., not to exceed a given radiation dose limit, if a site is to be used without radiological restriction. Generic guidelines for thorium and radium in soil, airborne radon decay products, external gamma radiation, surface contamination, and residual radionuclides in air and water are specified in DOE Order 5400.5 and other guidance. Soil guidelines for other radionuclides must be derived on a site-specific basis using RESRAD, the DOE residual radioactive material code (Gi89). Soil concentration guidelines have been calculated for 1000 years into the future. The lowest, most restrictive guideline calculated for this period is taken as the current soil guideline.

To derive site-specific soil guidelines, a basic radiation dose limit of $100 \mathrm{mrem} / \mathrm{yr}$, as specified by DOE, is normally applied to a member of the critical population group. The radiation dose limit is based on radiation protection standards and requirements specified in DOE Order 5400.5. However, since the drinking water pathway is expected to dominate the dose and since the State of South Carolina and the EPA National Primary Drinking Water Regulations (40CFR141.16) require the drinking water radiological dose 
to be less than the drinking water standard of $4 \mathrm{mrem} / \mathrm{yr}$, the guidelines generated here are based on a dose limit equal to the drinking water standard.

It is assumed, for the purpose of deriving soil guidelines, that the critical population group is a family that establishes residence on a site that has been released for use without radiological restrictions. The controlling principles for all guidelines are (1) the annual radiation dose received by a member of the critical population group from the residual radioactive material -- predicted by a realistic but conservative analysis and averaged over a time interval of 50 years -- should not exceed the basic dose limit and (2) doses should be kept as low as reasonably achievable (Gi89).

Since the $\mathrm{F}$ and $\mathrm{H}$ Areas are currently classified as industrial, soil guidelines for a worker scenario also have been calculated for comparison. These guidelines are determined in the same fashion as those for the future resident, except that fewer exposure pathways are considered. Therefore, guidelines to be protective of the industrial worker are expected to be less restrictive.

\section{DESCRIPTION OF RESRAD}

Models for deriving soil concentration guidelines from dose limits are simplified representations of complex processes. It is not feasible to obtain sufficient data to fully or accurately characterize transport and exposure processes. Similarly, it is not possible to predict future conditions with certainty. Hence, there will be uncertainties in the guideline values presented here. The models incorporated into RESRAD are very conservative, and the calculated doses corresponding to soil guideline values of the radionuclide concentrations are expected to be conservative estimates (overestimates) of actual doses. 
The most conservative exposure scenario (future resident farmer) is considered for the estimation of soil concentration guidelines. The resident farmer has no access restrictions and is assumed to be exposed to radioactive contaminants through the eight exposure pathways discussed below: 1) external ground-shine, 2) inhalation of resuspended dust, 3) ingestion of plant food, 4) ingestion of meat, 5) ingestion of milk, 6) ingestion of fish, 7) ingestion of groundwater, and 8) incidental ingestion of soil.

A less conservative, yet more realistic guideline, is generated for the F- and H-Area worker. These guidelines are determined considering the following exposure pathways: 1) external ground-shine, 2) inhalation of resuspended dust, 3) ingestion of groundwater, and 4) incidental ingestion of soil. Exposure parameters for each pathway are generally less restrictive that the resident farmer scenario.

Radon exposure was not considered when calculating these soil guidelines. The information in the section that follows is condensed from Gilbert et al. (1989).

External Radiation. Gamma radiation from radionuclides distributed throughout the contaminated zone is the dominant external radiation pathway and the only external pathway taken into account when calculating soil guidelines. The dose due to external gamma radiation is first calculated for an individual exposed continuously to radiation from an infinite contaminated zone at a distance of one meter from the ground surface. Correction factors are then applied for the finite area and thickness of the contaminated zone, shielding by a cover of contaminated soil, irregular shape, shielding by the floors and walls of a house, and less-than-continuous occupancy.

Inhalation. Inhalation exposure results primarily from inhalation of contaminated dust. Modeling the airborne exposure pathway segment consists of two steps: (1) modeling the process by which radionuclides become airborne and (2) modeling the process by which the airborne radionuclides are transported to a human exposure location and diluted before inhalation. The first step gives the ratio of the concentration in air near the source before it is dispersed and diluted to the concentration in the resuspended layer of dust; the second step gives the ratio of the airborne concentration at the point of exposure to the undiluted airborne concentration at the source.

Food Ingestion. Four food pathway categories are taken into account: plant foods, meat, milk, and aquatic foods. The food pathways are activated by scenarios in which crops are 
grown in or close to the contaminated zone. Plant crops grown in the contaminated zone will be the dominant and most frequent contributor, especially if the crops are irrigated with contaminated water. Contributors from the meat and milk pathways, which involve an additional pathway segment for transfer of radionuclides from fodder or water to the meat or milk, will generally be smaller but not insignificant. Vegetable gardens are common in urban and suburban areas as well as rural areas, whereas raising livestock is generally limited to rural areas. The aquatic food pathway should be considered only in areas where the topography and soil characteristics are favorable for building a pond.

Radionuclide transport through the food pathways is determined by the quantities of different foods consumed (dietary factors) and the fraction of the diet from foods that are contaminated by radionuclides from the contaminated zone (which is determined by the fraction raised locally and the area of the contaminated zone). Also important in radionuclide transport is the cover depth and contaminated zone thickness relative to the root zone of the plants, the various transfer factors from root or foliage to plants and from fodder or water to meat or milk, and the concentrations of radionuclides in water that has percolated down through the contaminated zone.

Water Pathway Segments. A water pathway segment connects the contaminated zone with a point of water withdrawal for drinking or irrigation or with a pond where aquatic foods are raised for human consumption (see Figure 1). It is characterized by a water/soil concentration ratio for each radionuclide, defined as the ratio of the radionuclide concentration in the water at the point of withdrawal to the radionuclide concentration in the contaminated zone. Irrigation and drinking water are assumed to be taken from a pond and well, respectively. The well is assumed to be at the down-gradient edge of the contaminated zone. The pond water is contaminated by water that seeps to the surface after percolating down through the contaminated zone. Natural precipitation or irrigation water infiltrates the contaminated zone and transports radionuclides through the vadose zone and the aquifer to a well or point of seepage into surface water.

The groundwater pathway models implemented in RESRAD apply only to situations for which the hydrological strata can reasonably be approximated by a sequence of uniform, horizontal strata. For sites having more complicated strata such as fracture zones, simple models may be used to provide reasonable estimates if a set of effective hydrogeologic flow parameters is used. The accuracy of the results is determined by the accuracy of the input parameters. 
The surface water is assumed to be a pond with an inflow dilution factor equal to the ratio of the annual volume of water that infiltrates the contaminated zone to the annual total inflow of water into the pond. Transport times from the contaminated zone to the pond are assumed to be the same as for the onsite well; no credit is taken for the additional time for radionuclides to be transported from the edge of the contaminated zone to the point of seepage. This simplified model will give a conservative estimate of the water/soil concentration ratio for a pond. The concentration factor that characterizes the drinking water pathway is obtained by multiplying the water/soil concentration ratio by the annual quantity of contaminated drinking water consumed by an individual.

\section{CONTAMINATED AREA CONCEPTUAL MODEL}

The Old F-Area Retention Basin. The contaminated zone at the Old F-Area Retention Basin is assumed to have lateral dimensions equal to the dimensions of the original retention basin $(61 \mathrm{~m} \times 37 \mathrm{~m})$. Based on previous excavation and soil sampling (Sc87), it was determined that the contaminated zone is approximately 2 meters deep with a cover soil thickness of 2.7 meters. The contamination is assumed to be uniformly distributed within the zone. The water table at the retention basin site is approximately 50 feet below the surface (Ni94), therefore, the distance from the bottom of the contaminated zone to the water table was calculated to be 10.5 meters. A schematic of the F-Area basin, the excavated area, and the contaminated zone dimensions is presented in Figure 2. On visual inspection of the site, it is apparent that an additional mound of soil was added as a cover to the Basin. Documentation on the physical dimensions of this additional cover is not available, therefore, the mounded soil dimensions are not included in the analysis. The contaminated area is located entirely in the vadose zone with a thick layer of unsaturated, clean soil separating it from the water table aquifer.

For purposes of estimating future exposures to basin contamination, it is assumed that the groundwater beneath the basin is currently free of contamination. Pathways involving exposure to groundwater and/or surface water contamination begin with no contribution to dose and increase over time as the contaminant moves through the soil and as the cover soil is eroded. Erosion of top soil occurs at a very slow rate of approximately 0.009 $\mathrm{cm} / \mathrm{yr}$ (Ro94). The height of the water table is assumed to change negligibly during the assessment period. 
The Old H-Area Retention Basin. The old retention basin in H-Area has the same lateral dimensions as that in F-Area $(61 \mathrm{~m} \times 37 \mathrm{~m})$. The H-Area basin, however, is currently uncovered and, due to very shallow groundwater at its location, it is assumed that all soil between the basin and the water table is contaminated (see Figure 3). The groundwater beneath the $\mathrm{H}$-Area basin is expected to be contaminated, however, since at the time of calculation the water concentrations were unknown, RESRAD is configured to estimate contaminant concentrations in groundwater. Once sampling wells are located in the area, measured and predicted concentrations can be compared to determine the accuracy of the RESRAD model.

Contamination extends beyond the boundaries of the Old H-Area Retention Basin. However, because the extent of contamination has not yet been quantified, the area is being modeled as though contamination exists only within the boundaries of the original basin. Contaminated areas outside of the basin have been identified by the Radiation Control and Health Physics Department and are marked accordingly to avoid unnecessary exposures.

General Site Parameters. All soils in both the unsaturated and saturated zones are assumed to have a sandy loam texture with a bulk density of about $1.6 \mathrm{~g} / \mathrm{cm}^{3}$ (Lo87), an effective porosity of 0.45 ( $\mathrm{Ha94}$ ), and a total porosity of 0.2 (Lo87). It is assumed that the radioactivity in the F- and H-Area basins was placed in early 1979 . This assumption does not affect the soil concentration guidelines generated in this report. The time of placement only affects the time at which the contamination reaches the water table, and since this study looks 1000 years into the future, the only significance placement time has on the output is the time at which the most restrictive guideline occurs.

RESRAD contains two groundwater transport models, either of which can be invoked. For this analysis the code has been configured to use a nondispersion model when calculating groundwater transport of radionuclides. This type of model assumes that the dispersion of nuclides is negligible, the unsaturated and saturated zones are homogenous, and that water withdrawn from the down-gradient well introduces only minor perturbations in groundwater flow. This model is different from the alternative, a mass balance model, which assumes that all of the radionuclides released from the contaminated zone are withdrawn through a well located at the center of the contaminated zone. The mass balance model is inappropriate for use with large $\left(>100 \mathrm{~m}^{2}\right)$ 
contaminated areas since all of the contamination is assumed to be retrieved through one well.

\section{PARAMETER VALUE ASSIGNMENTS}

Parameter values and references are presented in Tables 1 and 2 for all user inputs to RESRAD for the analyses of both the F- and H-Area basins. Several parameter values not normally adjusted by the user have been modified so that the transport and exposure models of RESRAD reflect values specific to the Savannah River Site (see Table 3). For example, the parameter value describing nuclide resuspension (mass loading) is based on atmospheric and soil concentrations of plutonium at locations on the SRS. Additionally, because of the extensive studies of cesium accumulation in fish conducted at this site, a site-specific bioconcentration factor for cesium is included in the RESRAD library. Leach rates specific to SRS soils also have been utilized when available (Lo87). 
Table 1. Soil characterization parameter values for modeling the Old F- and H-Area Retention Basins using RESRAD ${ }^{\dagger \dagger}$.

\begin{tabular}{|c|c|c|c|}
\hline Parameter & Value & Units & Reference \\
\hline Cover depth & $2.7(0)$ & $\mathrm{m}$ & Sc87 \\
\hline Contaminated area & 2250 & $\mathrm{~m}^{2}$ & Sc87 \\
\hline Contamination zone thickness & 2 & $\mathrm{n}$ & Sc87 \\
\hline Contamination length parallel to aquifer flow & 61 & $\mathrm{~m}$ & $\operatorname{Sc87}$ \\
\hline Unsaturated thickness below contamination & $10.5(0)$ & $\mathrm{m}$ & $\operatorname{Sc} 87$ \\
\hline Hydraulic gradient & $0.007(0.025)$ & - & Ge92 \\
\hline Well pump intake depth below water table & 10 & $\mathrm{~m}$ & $*$ \\
\hline Watershed area for nearby stream or pond & $1,000,000$ & $\mathrm{~m}^{2}$ & $\dagger$ \\
\hline Elapsed time of waste placement & 14 & $\mathrm{yr}$ & Sc87 \\
\hline Radiation dose limit & 4 & $\mathrm{mrem} / \mathrm{yr}$ & EPA DWS \\
\hline Precipitation rate & 1.2 & $\mathrm{~m} / \mathrm{yr}$ & Hu90 \\
\hline Irrigation rate & 0.76 & $\mathrm{~m} / \mathrm{yr}$ & Lo83 \\
\hline Well pumping rate & 250 & $\mathrm{~m}^{3} / \mathrm{yr}$ & $*$ \\
\hline Water table drop rate & 0 & $\mathrm{~m} / \mathrm{yr}$ & $\mathrm{Ha} 94$ \\
\hline Soil density & 1.6 & $\mathrm{~g} / \mathrm{cm}^{3}$ & Lo87 \\
\hline Erosion rate & 0.0009 & $\mathrm{~m} / \mathrm{yr}$ & Ro94 \\
\hline Total porosity & 0.45 & - & Ha94 \\
\hline Effective porosity & 0.2 & - & Lo87 \\
\hline Hydraulic conductivity & $378(3.15)$ & $\mathrm{m} / \mathrm{yr}$ & Ge92 \\
\hline b parameter (Table E. 2 of reference) & 4.5 & - & Gi89 \\
\hline Evapotranspiration coefficient & 0.42 & - & Hu87 \\
\hline Runoff coefficient & 0.025 & - & Hu87 \\
\hline
\end{tabular}


Table 2. Radiation exposure parameter values for the onsite resident and industrial worker scenarios in the execution of RESRAD ${ }^{\dagger}$.

\begin{tabular}{|c|c|c|c|}
\hline Parameter & Value & Units & Reference \\
\hline \multicolumn{4}{|l|}{ Exposure Factors } \\
\hline Inhalation rate & 8000 & $\mathrm{~m}^{3} / \mathrm{yr}$ & NRC77 \\
\hline Mass loading & 0.0002 & $\mathrm{~g} / \mathrm{m}^{3}$ & Gi89, Cu91 \\
\hline Dilution length for airborne dust & 3 & $\mathrm{~m}$ & Gi89 \\
\hline Exposure duration & $30(25)$ & $\mathrm{yr}$ & OERR91 \\
\hline Inhalation shielding factor & 0.4 & - & Gi89 \\
\hline External gamma shielding factor & 0.7 & - & Gi89 \\
\hline Ind sor time fraction & $0.5(0)$ & - & Gi89 \\
\hline Outdoor time fraction & $0.25(0.33)$ & - & Gi89 \\
\hline Vegetable consumpt ate & $276(0)$ & $\mathrm{kg} / \mathrm{yr}$ & Ha92 \\
\hline Leafy veg. consumpti & $43(0)$ & $\mathrm{kg} / \mathrm{yr}$ & $\mathrm{Ha92}$ \\
\hline Milk consumptinn rate & $230(0)$ & $\mathrm{L} / \mathrm{yr}$ & $\mathrm{Ha} 92$ \\
\hline Meat consumption rate & $81(0)$ & $\mathrm{kg} / \mathrm{yr}$ & Ha92 \\
\hline Fish consumption rate & $19(0)$ & $\mathrm{kg} / \mathrm{yr}$ & $\mathrm{Ha92}$ \\
\hline Soil ingestion rate & $35(12.5)$ & $\mathrm{g} / \mathrm{yr}$ & OERR91 \\
\hline Drinking water consumption rate & $730(370)$ & $\mathrm{L} / \mathrm{yr}$ & NRC77 \\
\hline Beef cattle fodder intake rate & 36 & $\mathrm{~kg} / \mathrm{d}$ & $\mathrm{Ha} 92$ \\
\hline Milk cattle fodder intake rate & 52 & $\mathrm{~kg} / \mathrm{d}$ & $\mathrm{Ha} 92$ \\
\hline Beef cattle water intake rate & 70 & $\mathrm{~L} / \mathrm{d}$ & Ma93 \\
\hline Milk cattle water intake rate & 110 & $\mathrm{~L} / \mathrm{d}$ & Ma93 \\
\hline Livestock soil intake & 0.5 & $\mathrm{~kg} / \mathrm{d}$ & Gi89 \\
\hline Depth of soil mixing layer & 0.15 & $\mathrm{~m}$ & Gi89, Pe83 \\
\hline Maximum root depth & 1 & $\mathrm{~m}$ & Pe83 \\
\hline Fraction of livestock water from ground & 0.56 & - & Lo83 \\
\hline Fraction of irrigation water from ground & 0.27 & - & Lo83 \\
\hline
\end{tabular}

†Values in parentheses are those used in the industrial worker scenario. 
Table 3. Contamination leach rates (Lo87) and default distribution coefficients (Gi87) utilized in RESRAD.

\begin{tabular}{|c|c|c|}
\hline Element & $\begin{array}{c}\text { Leach Rate } \\
(1 / y r)\end{array}$ & $\begin{array}{c}\mathrm{K}_{\mathrm{d}} \\
\left(\mathrm{cm}^{3} / \mathrm{g}\right)\end{array}$ \\
\hline Actinium & & 20 \\
\hline Americium & 0.00237 & \\
\hline Carbon & 1 & \\
\hline Cesium & 0.000474 & \\
\hline Cesium ${ }^{\dagger \dagger}$ & & 0 \\
\hline Cobalt & 0.023 .5 & \\
\hline Curium & 0.000075 & \\
\hline Europium & 1 & \\
\hline Gadolinium & 1 & \\
\hline Iodine & 0.732 & \\
\hline Manganese & & 200 \\
\hline Nickel & 0.00237 & \\
\hline Neptunium & 0.0235 & \\
\hline Lead & 0.00237 & \\
\hline Plutonium & 0.00237 & \\
\hline Potassium & & 5.5 \\
\hline Promethium & 1 & \\
\hline Protactinium & & 50 \\
\hline Radium & 0.00237 & \\
\hline Samarium & 1 & \\
\hline Sodium & & 10 \\
\hline Strontium & 0.0294 & \\
\hline Technetium & 1 & \\
\hline Thorium & 0.00237 & \\
\hline Tritium & 1 & \\
\hline Uranium & 0.00595 & \\
\hline Zinc & 0.0149 & \\
\hline
\end{tabular}

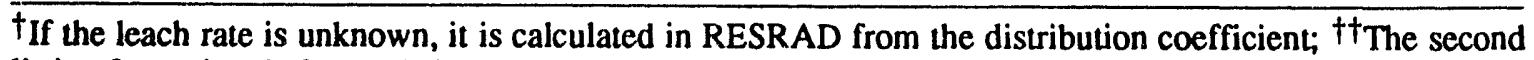
listing for cesium is for modeling the mobile fraction (approx. $0.1 \%$ ). 


\section{EXPOSURE SCENARIOS}

Future Resident. The critical population for the determination of soil concentration guidelines is the future resident farmer (Gi89). This scenario revolves around a family that is assumed to move onto the site after it has been released for use without radiological restrictions. The basic radiation limit used for the RESRAD calculation is 4 mrem/yr, pursuant to the National Drinking Water Standard.

The contaminated land is assumed to be inhabited by a resident farmer at some point in the future. One-hundred percent of the future resident's drinking water if obtained from an onsite well located at the down-gradient edge of the contaminated zone. A pond, located adjacent to the contaminated zone and in the direction of the ground flow, is utilized for $100 \%$ of the farmer's fish consumption. The resident farmer grows vegetables, meat, and milk on the contaminated site and consumes amounts of these foods proportional to the contaminated area available for production (as long as the consumption rates do not exceed those specified in Table 2). The farmer is also assumed to remain indoors $50 \%$ of the time, outdoors $25 \%$ of the time, and away from the area $25 \%$ of the time (Gi89).

Overhead irrigation of food crops is assumed to occur at a rate equal to the average irrigation rate for the State of South Carolina (30 inches/yr). Also in accordance with South Carolina statistics, $56 \%$ of livestock water and $27 \%$ of irrigation water is obtained from groundwater supplies, the balance is obtained from an adjacent, uncontaminated pond (Lo83).

Industrial Worker. A second exposure scenario is considered in which an SRS worker is exposed to radiological contaminants in the basins through direct radiation, inhalation of resuspended dust, consumption of groundwater, and incidental ingestion of soil. Exposure via these routes is considered excessive in that various controls are placed on a site worker to prevent the accumulation of unnecessary radiation dose.

The worker is assumed to be outdoors the entire work day (8 hours), ingesting soil at a rate of $50 \mathrm{mg} / \mathrm{d}$ for 250 days. The groundwater consumption rate for the SRS worker is assumed to be $370 \mathrm{~L} / \mathrm{yr}$. Again, the basic radiation limit is $4 \mathrm{mrem} / \mathrm{yr}$ even though the dose limit ic non-radiation workers at the Savannah River Site is $100 \mathrm{mrem} / \mathrm{yr}$. 


\section{RESULTS}

Future Resident. Soil guidelines for the nuclides present at the Old F- and H-Area Retention Basins have been calculated and are given in Tables 4 and 5, respectively. Also listed in the table are nuclide half-lives and the time over the next 1000 years at which the minimum soil guideline occurs (i.e., time at which the dose limit is reached). Soil guidelines are developed under the assumption that only one radionuclide is contaminating the soil. When multiple radionuclides are present, guidelines may have to be reduced so that the total dose from all nuclides does not exceed the basic dose limit.

Table 4. RESRAD soil guidelines for the Old F-Area Retention Basin site based on the residential scenario and a dose limit of $4 \mathrm{mrem} / \mathrm{yr}$.

\begin{tabular}{lccc}
\hline Nuclide & $\begin{array}{c}\text { Half-life } \\
\text { (yr) }\end{array}$ & $\begin{array}{c}\text { RESRAD } \\
\text { Soil Guideline } \\
\text { (pCi/g) }\end{array}$ & $\begin{array}{c}\text { Time of } \\
\text { Maximum } \\
\text { Dose (yr) }\end{array}$ \\
\hline C-14 & 5730 & 0.0035 & 0 \\
Cs-137 & 30.2 & $0.13^{*}$ & 0 \\
Eu-154 & 8.8 & $\dagger$ & 0 \\
Eu-155 & 4.96 & $\dagger$ & 1000 \\
H-3 & 12.3 & 0.46 & 0 \\
K-40 & $1.3 \mathrm{E} 9$ & 1.4 & 61 \\
Mn-54 & 0.86 & $5.1 \mathrm{E} 13$ & 0 \\
Ni-63 & 100.1 & $3.9 \mathrm{E} 7$ & 1000 \\
Pm-147 & 2.62 & $\dagger$ & 1000 \\
Sr-90 & 28.6 & 10 & 92 \\
Tc-99 & $2.13 \mathrm{E} 5$ & 0.019 & 0 \\
U-233 & $1.59 \mathrm{E} 5$ & 2.7 & 750 \\
U-234 & $2.45 E 5$ & 2.5 & 750 \\
U-235 & $7.04 \mathrm{E} 8$ & 0.74 & 660 \\
U-238 & $4.47 \mathrm{E} 9$ & 2.6 & 750 \\
Zn-65 & 0.67 & $7.6 \mathrm{E} 14$ & 0 \\
\hline
\end{tabular}

\footnotetext{
"based on mobile fraction of $0.1 \%$; ${ }^{\dagger}$ at specific activity level.
} 
Table 5. RESRAD soil guidelines for the Old H-Area Retention Basin site based on the residential scenario and a dose limit of $4 \mathrm{mrem} / \mathrm{yr}$.

\begin{tabular}{|c|c|c|c|}
\hline Nuclide & $\begin{array}{l}\text { Half-life } \\
(y r)\end{array}$ & $\begin{array}{l}\text { RESRAD } \\
\text { Soil Guideline } \\
\text { (pCi/g) }\end{array}$ & $\begin{array}{c}\text { Time of } \\
\text { Maximum } \\
\text { Dose (yr) }\end{array}$ \\
\hline Am-241 & 432.2 & 3.3 & 0 \\
\hline C-14 & 5730 & 0.068 & 0 \\
\hline $\mathrm{Cm}-243$ & 28.5 & 0.0013 & 340 \\
\hline $\mathrm{Cm}-244$ & 18.1 & 6.7 & 0 \\
\hline Co-60 & 5.271 & 0.28 & 0 \\
\hline Cs-137 & 30.2 & 1.2 & 0 \\
\hline Eu-152 & 13.33 & 0.29 & 0 \\
\hline Eu-154 & 8.8 & 0.23 & 0 \\
\hline Eu-155 & 4.96 & 2.5 & 0 \\
\hline H-3 & 12.3 & 44 & 0 \\
\hline I-129 & $1.57 \mathrm{E} 7$ & 0.017 & 0 \\
\hline $\mathrm{K}-40$ & $1.3 \mathrm{E} 9$ & 2 & 0 \\
\hline $\mathrm{Na}-22$ & 2.602 & 0.41 & 0 \\
\hline $\mathrm{Pm}-147$ & 2.62 & 3.7 & 0 \\
\hline $\mathrm{Pu}-238$ & 87.74 & 3.9 & 0 \\
\hline $\mathrm{Pu}-239$ & 24119 & 3.2 & 0 \\
\hline $\mathrm{Pu}-240$ & 6570 & 3.4 & 330 \\
\hline $\mathrm{Ra}-226$ & 1600 & 0.18 & 54 \\
\hline Sr-90 & 28.6 & 0.55 & 0 \\
\hline Tc-99 & $2.13 \mathrm{E} 5$ & 1.5 & 0 \\
\hline U-233 & $1.59 \mathrm{E} 5$ & 16 & 360 \\
\hline U-234 & $2.45 \mathrm{E} 5$ & 18 & 0 \\
\hline U-235 & $7.04 \mathrm{E} 8$ & 5.3 & 0 \\
\hline U-238 & 4.47E9 & 14 & 0 \\
\hline
\end{tabular}

Generally, the water consumption pathway dominates the guidelines generated for the FArea basin. However, due to the physical setting at the H-Area basin, external exposure, 
inhalation, vegetation consumption, and water consumption are all important exposure pathways when estimating the soil guidelines for the Old H-Area Retention Basin. Generally, the external gamma exposure, food consumption, and inhalation pathways dominate in the earlier years with the groundwater and surface water pathways increasing in significance once nuclides migrate from the contaminated zone and reach the water table. Some nuclides have such short half-lives that they decay before reaching the groundwater. Others, however, have very long half-lives and result in greater exposures once reaching the water dependent pathways.

A small fraction of cesium contamination has been shown to be mobile in soils at the Savannah River Site. Approximately $0.1 \%$ of cesium moves quickly through soil. This migration is assumed to occur unretarded $\left(\mathrm{K}_{d}=0\right)$ and significantly reduces the Cs-137 soil guideline at the F-Area retention basin. Cesium exposure at the H-Area basin, however, is predominantly external due to the presence of Cs-137 at the surface. If a small fraction of that cesium is assumed to be mobile, the external dose is reduced (increasing the soil guideline) since a fraction of the surface contamination is being removed through ground transport.

Industrial Worker. Soil concentration guidelines based on the industrial worker scenario are given in Tables 6 and 7 for the F- and H-Area basins, respectively. Except for a few cases, the F-Area guidelines for workers are approximately twice the guidelines derived for the resident. This increase is due to the reduction in drinking water amounts for the worker by a factor of 2 and the significance of the drinking water pathway. H-Area worker guidelines are generally a factor of 2 to 3 higher than the resident guidelines, again due to the significance of the drinking water pathway, but also due to differences in external exposure duration. 
Table 6. RESRAD soil guidelines for the Old F-Area Retention Basin site based on the industrial worker scenario and a dose limit of $4 \mathrm{mrem} / \mathrm{yr}$.

\begin{tabular}{lcc}
\hline Nuclide & $\begin{array}{c}\text { RESRAD } \\
\text { Soil Guideline } \\
\text { (pCi/g) }\end{array}$ & $\begin{array}{c}\text { Time of } \\
\text { Maximum } \\
\text { Dose }(\mathrm{yr})\end{array}$ \\
\hline C-14 & 0.029 & \\
Cs-137 & $0.36^{*}$ & 0 \\
Eu-154 & $\dagger$ & 0 \\
Eu-155 & $\dagger$ & 0 \\
H-3 & 0.98 & 1000 \\
K-40 & 3.4 & 0 \\
Mn-54 & $9.4 \mathrm{E} 13$ & 61 \\
Ni-63 & $9.6 \mathrm{E} 7$ & 0 \\
Pm-147 & $\dagger$ & 1000 \\
Sr-90 & 23 & 1000 \\
Tc-99 & 0.047 & 92 \\
U-233 & 5.9 & 0 \\
U-234 & 5.6 & 750 \\
U-235 & 1.6 & .750 \\
U-238 & 5.8 & 660 \\
Zn-65 & $1.4 E 15$ & 750 \\
& & 0 \\
\hline
\end{tabular}

"based on mobile fraction of $0.1 \%$; ${ }^{\dagger}$ at specific activity level. 
Table 7. RESRAD soil guidelines for the Old H-Area Retention Basin site based on the industrial worker scenario and a dose limit of $4 \mathrm{mrem} / \mathrm{yr}$.

\begin{tabular}{|c|c|c|}
\hline Nuclide & $\begin{array}{l}\text { RESRAD } \\
\text { Soil Guideline } \\
(\mathrm{pCi} / \mathrm{g})\end{array}$ & $\begin{array}{c}\text { Time of } \\
\text { Maximum } \\
\text { Dose }(y r)\end{array}$ \\
\hline$A m-241$ & 13 & 79 \\
\hline C-14 & 3.7 & 0 \\
\hline $\mathrm{Cm}-243$ & 0.0030 & 340 \\
\hline $\mathrm{Cm}-244$ & 28 & 0 \\
\hline Co-60 & 0.52 & 0 \\
\hline Cs- 137 & 2.4 & 0 \\
\hline Eu-152 & 0.60 & 0 \\
\hline Eu-154 & 0.48 & 0 \\
\hline Eu-155 & 5.6 & 0 \\
\hline H-3 & 130 & 0 \\
\hline I-129 & 0.040 & 0 \\
\hline $\mathrm{K}-40$ & 8.3 & 0 \\
\hline $\mathrm{Na}-22$ & 0.76 & 0 \\
\hline Pm-147 & 8.4 & 0 \\
\hline $\mathrm{Pu}-238$ & 15 & 0 \\
\hline $\mathrm{Pu}-239$ & 15 & 0 \\
\hline $\mathrm{Pu}-240$ & 8.1 & 920 \\
\hline $\mathrm{Ra}-226$ & 0.76 & 54 \\
\hline Sr-90 & 29 & 13 \\
\hline Tc-99 & 6.1 & 0 \\
\hline U-233 & 37 & 360 \\
\hline U-234 & 44 & 360 \\
\hline U-235 & 11 & 0 \\
\hline U-238 & 36 & 0 \\
\hline
\end{tabular}

Uncertainties obviously exist in the soil guidelines, primarily because of uncertainties in the parameters used to describe soil characteristics. Groundwater transport modeling 
uncertainties range from nil, because groundwater movement is not significant to exposure by a particular nuclide, to very high, depending on groundwater modeling assumptions.

\section{REMEDIATION SCENARIOS}

\section{RESULT OF CAPPING THE OLD F-AREA RETENTION BASIN}

Among the remedial alternatives is the option of placing an impermeable cap over the contaminated soil at the Old F-Area Retention Basin. The capping material dramatically decreases the amount of water at the surface that percolates through the contaminated zone thereby reducing the amount of contamination reaching the water table. RESRAD was not designed to model contaminant migration under different remediation scenarios. However, the degree to which the infiltration is reduced was modeled in RESRAD by varying the amount of rainfall and irrigation incident on the basin site, effectively modeling the reduced flux of rainwater due to the cap. With reduced infiltration, movement of contamination decreases dramatically and soil concentration guidelines increase.

A plot of soil concentration guidelines versus infiltration reduction factor is given in Figure 4 for the transport of strontium. The reduction factor is simply the factor by which precipitation and irrigation rates were decreased in subsequent executions of RESRAD. The actual precipitation and irrigation rates for the Savannah River Site are $1.2 \mathrm{~m} / \mathrm{yr}$ and $0.76 \mathrm{~m} / \mathrm{yr}$, respectively, for a total incident water fall of $1.96 \mathrm{~m} / \mathrm{yr}$. An infiltration reduction factor of four, for example, results in precipitation and irrigation rates totaling $0.49 \mathrm{~m} / \mathrm{yr}$.

The relationship between soil concentration guide and infiltration is log-linear with the reduction factor equaling the orders of magnitude increase in soil guideline, e.g., a reduction factor of six results in an increase in the soil guideline of six orders of magnitude.

The ability of a cap to reduce the percolation rate of water at the surface is generally expressed in terms of its hydraulic conductivity. The relationships between precipitation and infiltration rate (percolation) and between percolation and hydraulic conductivity are shown graphically in Figures 5 and 6, respectively. These figures show that the hydraulic 
conductivity related to average precipitation with no cap is about $0.001 \mathrm{~cm} / \mathrm{s}$ with a percolation rate of about $11 \mathrm{in} / \mathrm{yr}$ at the Savannah River Site. Decreasing the hydraulic conductivity two orders of magnitude (to the point of the standard clay cap) results in percolation rates of less than about $0.2 \mathrm{in} / \mathrm{yr}$. This percolation rate is associated with a precipitation rate of about $30 \%$ of normal, or an infiltration reduction of about a factor of three. Examination of Figure 4 reveals that reducing infiltration by a factor of three results in an increase of the soil concentration guideline for strontium of about three orders of magnitude. Therefore, capping materials with hydraulic conductivities less than $0.00001 \mathrm{~cm} / \mathrm{s}$ result in soil concentration guidelines greater than three orders of magnitude than presented in Tables 4 through 7 (using strontium as an example.)

\section{SCENARIO FOR MOVING H FLOOD AREA SOILS TO THE F BASIN}

As stated earlier, because of basin flooding, some contamination from the Old H-Area Retention Basin has been carried over the surface to a small discharge creek located down-gradient and to the south. This discharge creek is also fed by a storm water discharge outfall (HP52) from the H-Area Tank Farm. The HP52 outfall, as well as the historical flooding of the retention basin, has resulted in contamination of the stream bank. The area between the stream and the basin are more heavily contaminated than other areas along the bank.

Possible remediation alternatives include moving some of the lesser contaminated soils from the HP52 outfall stream bank to the Old F-Area Retention Basin. This action would involve removing the backfill that was placed over the contaminated soil at the F-Area basin in 1979 and replacing it (all but the top two feet) with the outfall contaminated soil. The concentration of radionuclides in the soils from HP52 are less than those already present at the Old F-Area Retention Basin. Two feet of clean fill would be placed over the newly placed contaminated soil and the whole basin covered with an impermeable cap.

As examples of the affect of this remediation alternative, soil concentration guidelines have been calculated for Sr-90, Cs-137, and Pu-239 using the resident scenario and a contaminated zone as described above. The guidelines, however, do not consider the effectiveness of any type of capping material that may be used. Physically, the lateral extent of the contaminated area and the thickness of clean soil between the contaminated zone and the water table does not change. The only modifications made to the RESRAD 
model are that the amount of cover soil changes from about 6 feet ( 2.7 meters) to 2 feet ( 0.61 meters) so that the contaminated zone is now 4.9 meters thick.

The soil concentration guidelines generated with the new assumptions are shown in Table 8 compared with the guidelines calculated under current conditions. The guidelines for Cs-137 are driven by the assumption that a small fraction $(0.1 \%)$ of the cesium is mobile without retardation. The dose resulting from Cs-137 with this assumption is dominated by the water dependent pathways, i.e., drinking water, fish consumption, and vegetable consumption. Plutonium-239 was not detected in the soils at the F-Area basin, therefore, no comparison for this nuclide is available.

Table 8. Comparison of soil guidelines with and without the addition of HP52 stream contamination into the Old F-Area Retention Basin.

\begin{tabular}{lcccc}
\hline Nuclide & $\begin{array}{c}\text { HP52 Soil } \\
\text { in F-Basin } \\
\text { Guideline }\end{array}$ & $\begin{array}{c}\mathrm{t}^{*} \\
(\mathrm{yr})\end{array}$ & $\begin{array}{c}\text { Original } \\
\text { F-Basin } \\
\text { Guideline }\end{array}$ & $\begin{array}{c}\mathrm{t}^{*} \\
(\mathrm{yr})\end{array}$ \\
\hline Sr-90 & 0.53 & 44 & 10 & 92 \\
$\mathrm{Cs}-137$ & $0.0023^{* *}$ & 0 & $0.13^{* *}$ & 0 \\
$\mathrm{Pu}-239^{\dagger}$ & 15 & 500 & - & - \\
\hline
\end{tabular}

" $t$ is the time into the future when the maximum dose (minimum concentration guideline) is achieved; ${ }^{* *}$ the cesium guideline was determined assuming $0.1 \%$ of cesium is mobile without retardation; ${ }^{\dagger} \mathrm{Pu}-239$ is not currently present in the soil at the Old F-Area Retention Basin. 


\section{REFERENCES}

(Cu91) Cummins, C.L.; Martin, D.K.; Todd, J.L. Savannah River Site enviromental report for 1990. Westinghouse Savannah River Company. Aiken, SC: Report No. WSRC-IM-91-28; 1991.

(Ge92) Geotrans. Groundwater flow model for the general separations area, Savannah River Site. GeoTrans, Inc. Aiken, SC: Project No. 3017-003; 1992.

(Gi89) Gilbert, T.L.; Yu, C.; Yuan, Y.C.; Zielen, A.J.; Jusko, M.J.; Wallo, A. A manual for implementing residual radioactive material guidelines. Argonne National Laboratory. Argonne, IL: Report No. ANL/ES-160; 1989, 1-203.

(Ha92) Hamby, D.M. Site-specific parameter values for the Nuclear Regulatory Commissions food pathway dose model. Health Physics. 62:136-143; 1992.

(Ha93) Hamby, D.M. Soil concentration guidelines for the Savannah River Site using the DOE/RESRAD methodology. Westinghouse Savannah River Company. Aiken, SC: Report No. WSRC-TR-93-304; 1993.

(Ha94) Haselow, J.S. Westinghouse Savannah River Company. personal communcation. January 4, 1994.

(Hu87) Hubbard, J.E.; Englehardt, M. Calculation of groundwater recharge at the old SRP burial ground using the CREAMS model (1961-1986). E.I. duPont de Nemours \& Company. Aiken, SC: Report No. DPMS-87-126; 1987, 1 11.

(Hu90) Hunter, C.H. A climatological description of the Savannah River Site. Westinghouse Savannah River Comany. Aiken, SC: Report No. WSRC-RP89-313; 1990.

(ICRP91) International Commission on Radiological Protection. Risks associated with ionising radiations. Pergamon Press. New York, NY: Vol. 22, No. 1; 1991. 
(Lo83) Lonon, G.E.; Burnette, C.B.; Morris, H.J. Water use in South Carolina, 1980. South Carolina Water Resources Commission. Columbia, SC: Report No. $138 ; 1983$.

(Lo87) Looney, B.B.; Grant, M.W.; King. C.M. Estimation of geochemical parameters for assessing subsurface transport at the Savannah River Plant. E.I. duPont de Nemours \& Company. Aiken, SC: Report No. DPST-85-904; 1987.

(Ma93) Mathis, T. Aiken County Extension Service. personal communication. March 10, 1993.

(Ni94) Nix, D.W. Depth to water table at old F-Area retention basin. personal communication. January 18, 1994.

(OERR91) Office of Emergency and Remedial Response. Standard default exposure factors. Supplemental Guidance. Washington, DC: Report No. OSWER 9285.6-03; 1991.

(Pe83) Peterson, H.T. Terrestrial and aquatic food chain pathways. In: Radiological Assessment. (J.E. Till; H.R. Meyer, eds.). Nuclear Regulatory Commission. Washington, DC: Report No. NUREG/CR-3332; 1983.

(Ro94) Rogers, V.A. Erosion factor for waste site cap. Westinghouse Savannah River Company. Aiken, SC: Report No. SRT-ESS-94-113. 1994.

(Sc87) Scott, S.C.; Killian, T.H.; Kolb, N.L.; Corbo, P.; Marine, I.W. Separations area retention basins. E.I. duPont de Nemours \& Company. Aiken, SC: Report No. DPST-85-693; 1987.

(EPA91) U.S. Environmental Protection Agency. Risk assessment guidance for Superfund: Volume 1 - Human health evaluation manual (Part B, Development of risk-based preliminary remediation goals). Office of Emergency and Remedial Response. Washington, DC: Report No. 9285.701B; 1991. 
(NRC77) U.S. Nuclear Regulatory Commission. Calculation of annual doses to man from routine releases of reactor effluents for the purpose of evaluating compliance with 10 CFR Part 50, Appendix I. Washington, DC: Regulatory Guide 1.109, Rev. 1; 1977. 
Figure 1

RESRAD Schematic of the Nondispersion Model

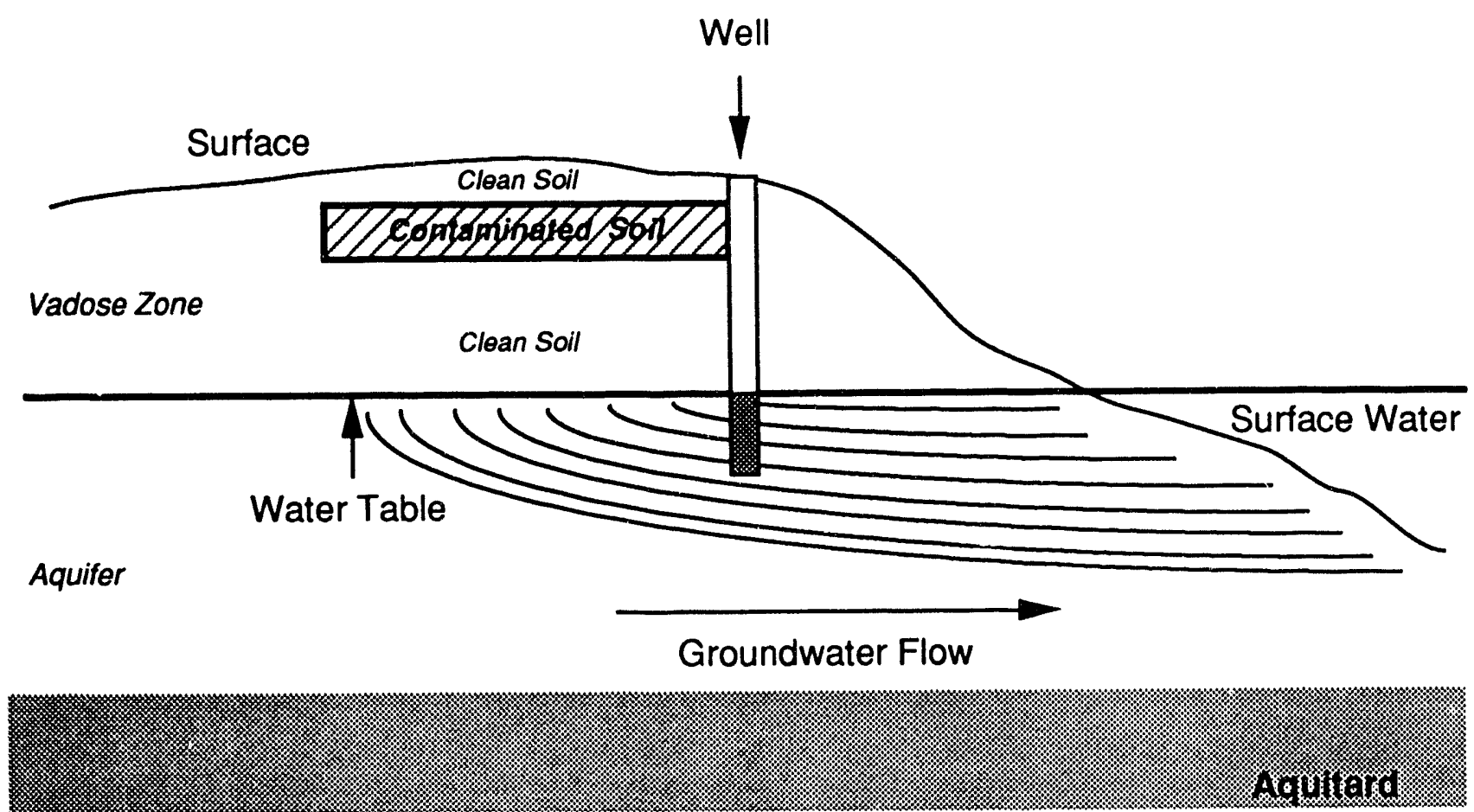


Figure 2

Conceptualization of F-Area Retention Basin Contamination

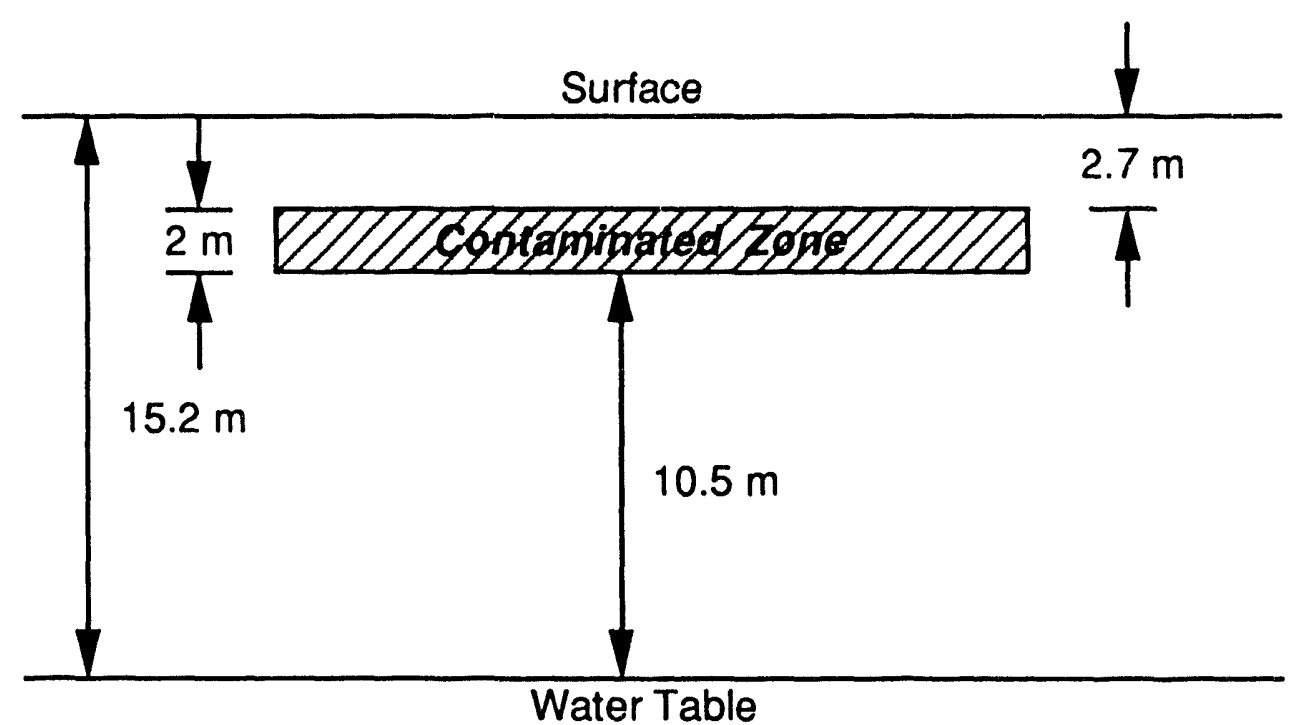


Figure 3

Conceptualization of H-Area Retention Basin Contamination

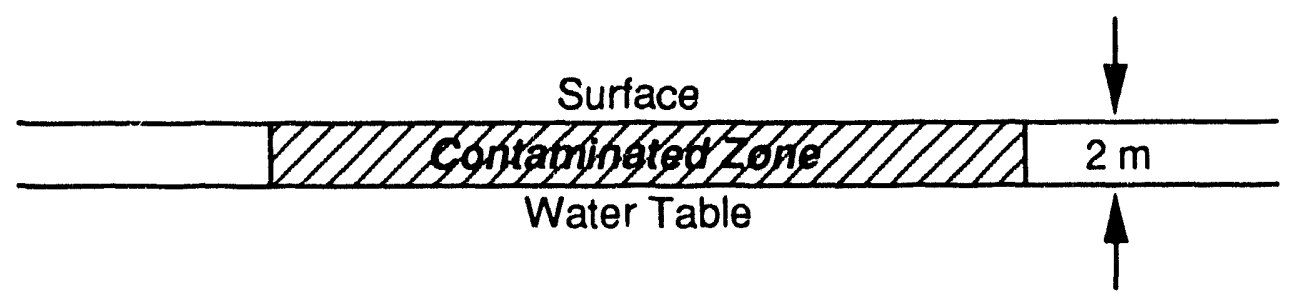


Figure 4. Concentration Guideline (Sr-90) as a Function of Infiltration

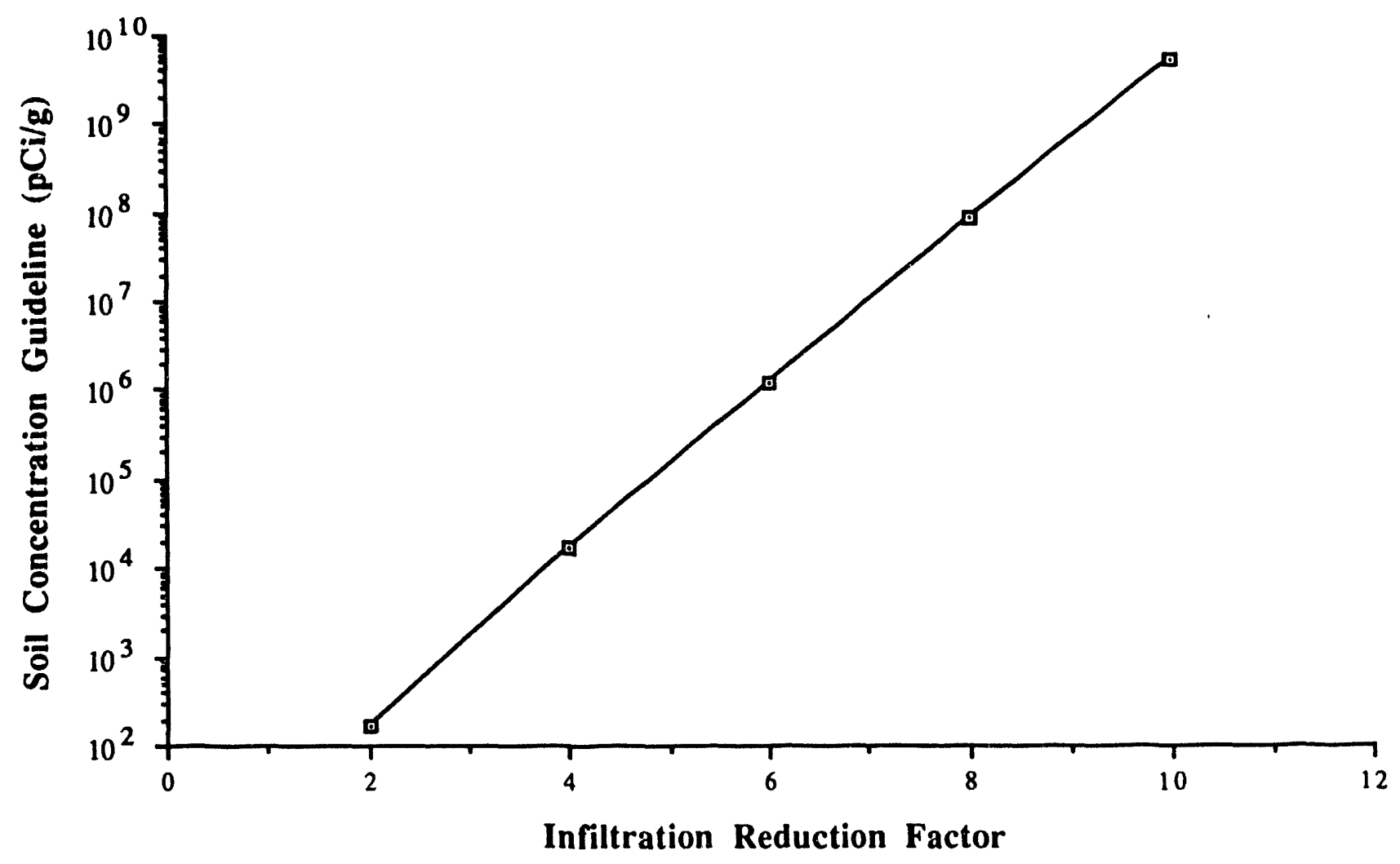


Figure 5. Runs of HELP Model to Evaluate Cap Effect

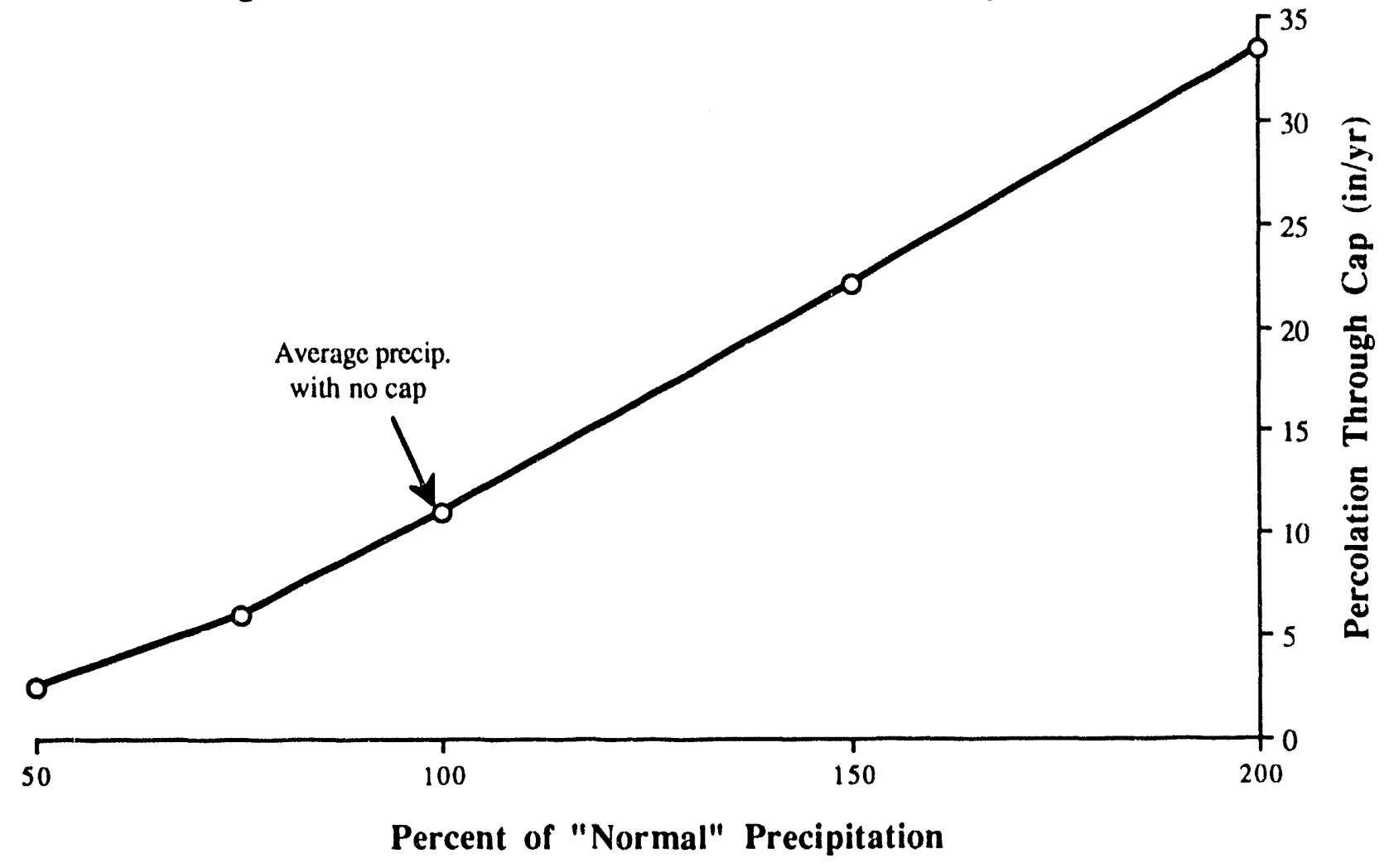

(reproduced from graph supplied by Neptune \& Company)

Figure 6. Runs of HELP Model to Evaluate Cap Effect

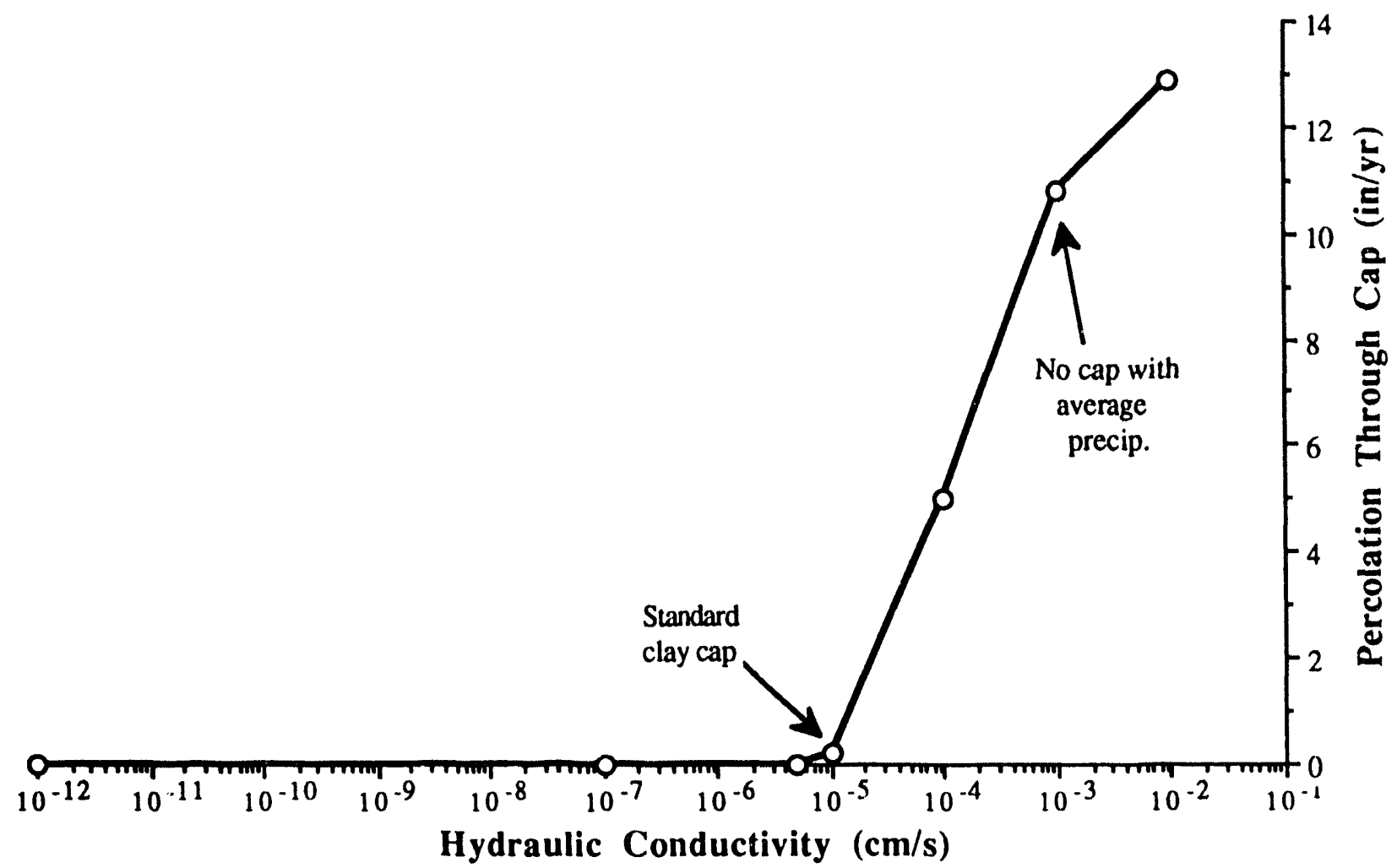


GUIDELINES FOR ACCEPTABLE SOIL CONCENTRATIONS IN THE OLD F- AND H-AREA RETENTION BASINS

P.B. Barnard, 742-A

A.L. Boni, 773-A

W.H. Carlton, 773-A

D.M. Hamby, 773-A

J. Immel, 992-4W

W.F. Johnson, 992-4W

K.J. Kuelske, 992-4W

W.C. Miles, $992-W$

D.W. Nix, 992-4W

A.A. Simpkins, 773-A

SRTC Records (4)

EDG Files (2) 

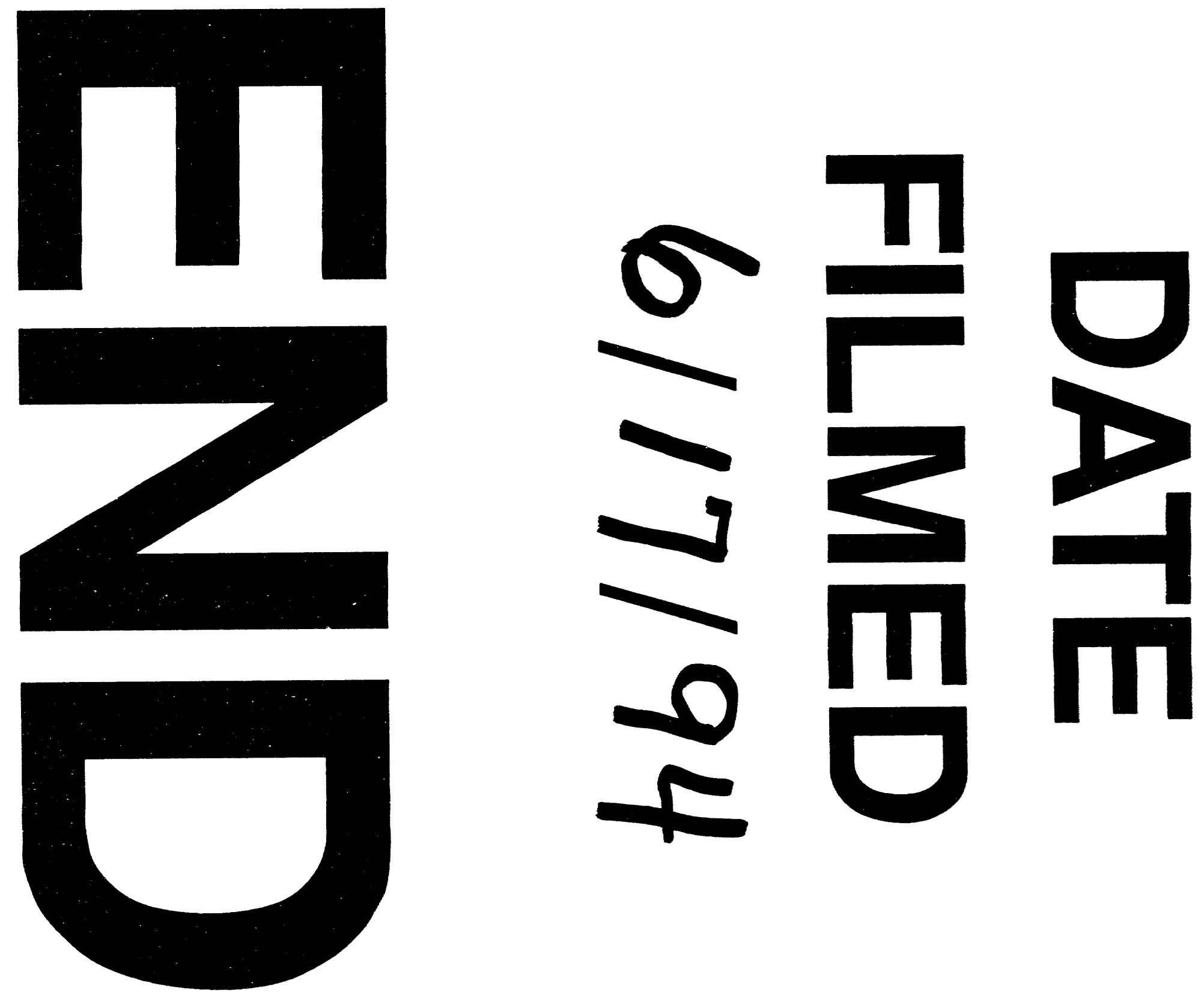
